University of Warwick institutional repository: http://go.warwick.ac.uk/wrap This paper is made available online in accordance with publisher policies. Please scroll down to view the document itself. Please refer to the repository record for this item and our policy information available from the repository home page for further information.

To see the final version of this paper please visit the publisher's website. Access to the published version may require a subscription.

Author(s): Sarah C. WATKINSON, Kerry S. BURTON and David A. Wood

Article Title: Characteristics of intracellular peptidase and proteinase activities from the mycelium of a cord-forming wood decay fungus Serpula lacrymans

Year of publication: 2001

Link to published version:

http://dx.doi.org/10.1017/S0953756201003938

Publisher statement: None 


\title{
Characteristics of intracellular peptidase and proteinase activities from the mycelium of a cord-forming wood decay fungus, Serpula lacrymans
}

\author{
Sarah C. WATKINSON, ${ }^{1}$ Kerry S. BURTON ${ }^{2}$ and David A. Wood $†$ \\ ${ }^{1}$ Department of Plant Sciences, University of Oxford, South Parks Road, Oxford OX1 3RB, UK. \\ ${ }^{2}$ Horticulture Research International, Wellesbourne, Warwick CV35 9EF, UK. \\ E-mail:sarah.watkinson@plant-sciences.ox.ac.uk \\ Received 22 July 2000; accepted 1 December 2000.
}

\begin{abstract}
Serpula lacrymans is a basidiomycete cord-forming wood decay fungus which reallocates nitrogen within an extensive perennial mycelial system in response to spatial discontinuities in external nutrient supply. Intracellular stored protein is mobilised by conversion to amino acids at nutrient-poor sites within a mycelium or when a whole mycelium is starved. Intracellular peptidase and proteinase activities of the mycelium were investigated with the aim of identifying proteases specifically activated in response to a nitrogen demand. Mycelium for enzyme extraction grown as surface mats in static liquid culture was homogenised, and the extract used in assays for proteinase and peptidase with various synthetic peptide substrates conjugated to 4-nitroaniline. Activities against different substrates were characterised with respect to $\mathrm{pH}$, inhibitor sensitivity, requirements for divalent metal ions, isoelectric point, and by changes in activities in starved mycelium. Four different activities were found, comprising two peptidases one of which had metalloprotease characteristics, a serine-type proteinase, and a proteinase active at $\mathrm{pH} 2.5$ which was not affected by any of the inhibitors tried. Both the latter were most active in starved mycelium. Isoelectric focusing showed peaks with activities corresponding to the serine-type proteinase and one of the manganese-activated peptidases. Possible roles for these enzymes in nitrogen reallocation during mycelial foraging are discussed.
\end{abstract}

\section{INTRODUCTION}

Mycelium of saprotrophic and ectomycorrhizal cord forming fungi accumulates, immobilises and redistributes significant amounts of nitrogen within their habitats, thereby affecting the process of wood decomposition (Dighton 1997, Boddy \& Watkinson 1995). Nitrogen accumulated from wood (Watkinson, Davison \& Bramah 1981) and from the environment is stored in the mycelium as protein, which is hydrolysed when mycelium is starved of nitrogen (Venables \& Watkinson 1989a), and transported through the mycelial network (Watkinson 1984), probably in the form of amino acids, to support new growth and colonisation of woody resources. Fungi forming such distributive networks include the woodland decomposer Phanerochaete velutina, the ectomycorrhizal Suillus bovinus, and the timber dry rot fungus Serpula lacrymans, reviewed respectively by Boddy (1993), Leake \& Read (1997), and Watkinson (1999). In mycelial foraging, biomass is preferentially allocated to cord development in those parts of the hyphal network which encounter and colonise fresh food sources. Other parts of the mycelium which do not connect to fresh resources are autolysed and resorbed, a process which presumably involves local activation of intracellular hydrolases. The signal

+ Deceased. transduction pathway for the resource reallocation response following encounter with a localised fresh food source is not known. This investigation of intracellular proteases was undertaken in a search for the specific proteinases activated when non-bridging mycelium regresses. Ultimately, purification of enzymes could lead to development of a cellular reporter for an autolysis-inducing signal. Wadekar, North \& Watkinson (1995) characterised four distinct proteinase activities of S. lacrymans by using SDS-PAGE to characterise bands in terms of inhibitor sensitivity and $\mathrm{pH}$ optima, and hydrolysis of azocasein to quantify net proteolytic activity in mycelial extracts. The purpose of using a range of synthetic substrates in this investigation was to differentiate the different protease activities present in mycelium, and to quantify and further characterise them, as a basis for investigating their physiological roles.

\section{MATERIALS AND METHODS}

\section{Organism and culture}

Culture

Serpula lacrymans, culture $12 \mathrm{C}$ from the Forest Products Laboratory (Building Research Establishment, Garston, Watford), was subcultured and maintained on $2 \%$ malt agar $\left(20 \mathrm{~g} \mathrm{l}^{-1}\right.$ malt extract, $15 \mathrm{~g} \mathrm{l}^{-1}$ Oxoid no. 3 agar) at $22{ }^{\circ} \mathrm{C}$. 


\section{Growth of mycelium and preparation of extracts for assays}

Conical flasks, capacity $250 \mathrm{ml}$ or $50 \mathrm{ml}$, containing respectively 50 or $20 \mathrm{ml}$ of modified Czapek-Dox medium ( $\mathrm{g}$ $\mathrm{l}^{-1}$ : glucose 2; Oxoid bactopeptone $1 ; \mathrm{KH}_{2} \mathrm{PO}_{4}, 1 ; \mathrm{KCl}, \mathrm{I}$; $\mathrm{MgSO}_{4} \cdot 7 \mathrm{H}_{2} \mathrm{O}, 0.5 ; \mathrm{FeSO}_{4} \cdot 7 \mathrm{H}_{2} \mathrm{O}, 0.01$ ), inoculated with $10 \mathrm{~mm}$ agar plugs cut submarginally from a 10-d-old agar culture and floated on the surface of the medium, were incubated for three to five weeks at $22{ }^{\circ} \mathrm{C}$. Except where otherwise stated, mycelium was separated from the medium by vacuum filtration on nylon mesh, washed with $100 \mathrm{~mm}$ icecold $\mathrm{KH}_{2} \mathrm{PO}_{4} / \mathrm{Na}_{2} \mathrm{HPO}_{4}$ buffer $\mathrm{pH} 6.5$, and fragmented by grinding in a mortar with a further $5-10 \mathrm{ml}$ ice-cold buffer. The resulting mycelial fragments were homogenised with a Polytron homogeniser run at half maximum speed. The homogenate was centrifuged at $35000 \mathrm{~g}$ for $20 \mathrm{~min}$ at $0^{\circ}$, and the supernatant kept ice cold until used in the assay.

For analysing the effects of starvation, the peptone medium listed above was carefully removed by pipette, without damaging the floating mycelial mat, and replaced by saltsonly medium in which the glucose and bactopeptone were omitted. Cultures were initially grown for 3 weeks in $50 \mathrm{ml}$ flasks each containing $25 \mathrm{ml}$ peptone medium. Experimental cultures were selected to be at a similar stage of growth, with mycelial mats just reaching the sides of the flask. The duration of the starvation period was varied by exchanging full medium for salts-only medium in two duplicate sets of three flasks at 4, 3, 2 and $1 \mathrm{~d}$ before the determination of enzyme activities, with two sets kept on full medium as a control. Mycelial mats were harvested in pooled sets of three from each set of replicate flasks, rapidly blotted on cellulose tissue and transferred to liquid nitrogen, then ground with a pestle. Fragments were suspended in $5 \mathrm{ml}$ ice-cold $100 \mathrm{~mm}$ Tris/ $\mathrm{HCl}$ buffer ( $\mathrm{pH}$ 8.5). The mixture was homogenised and centrifuged as above. The supernatants from pooled mycelium harvested at each sampling period were assayed for activity with four substrates, and for protein by the assay of Bradford (1976).

\section{Proteinase assays}

Initial screen for suitable substrates

To assess the range of activities present various peptide substrates conjugated with $p$-nitroanilide were used. For $3 \mathrm{~mm}$ stock solutions, peptidase and proteinase substrates were dissolved in dimethyl formamide. Culture filtrate samples $(50 \mu \mathrm{l})$ were added to microtitre plate wells each containing approx. $200 \mu \mathrm{l}$ of stock solutions of synthetic peptidase or proteinase substrates diluted to $0.15 \mathrm{~mm}$ in three buffers to cover three $\mathrm{pH}$ values: $0.1 \mathrm{M}$ sodium acetate/acetic acid ( $\mathrm{pH}$ 5.0), $0.1 \mathrm{~m}$ sodium phosphate/phosphoric acid ( $\mathrm{pH} 7.0$ ) and $0.1 \mathrm{~m}$ sodium carbonate $/ \mathrm{HCl}(\mathrm{pH} 9.5)$. Further assays of some substrates were carried out over a wider range with buffers including $0.1 \mathrm{~m}$ glycine $/ \mathrm{HCl}(\mathrm{pH} 2.5)$. All synthetic substrates contained $p$-nitroanilide (pNA) coupled to the $\alpha$ carboxylic group of a single amino acid or short peptide (two to four amino acid residues in length). Some of the substrates were blocked on the $\mathrm{NH}_{2}$-terminus by either succinyl (Suc) or benzoyl (Bz) groups to prevent aminopeptidase action, but others were not blocked. The plates were agitated to mix, and covered with clingfilm for 1 hour's incubation at $35^{\circ}$, after which enzyme activity was assessed as light absorbance at $405 \mathrm{~nm}$ wavelength, using an ELISA plate reader.

\section{Enzyme assays}

Activities against $0.15 \mathrm{~mm}$ peptide substrates were measured by addition of 50 or $100 \mu \mathrm{l}$ culture filtrate to the substrate in 950 or $900 \mu \mathrm{l}$ of $100 \mathrm{~mm}$ buffer at $35^{\circ}$. Initial rate of increase in $A_{405}$ was measured continuously for $10 \mathrm{~min}$ in a recording dual-beam spectrophotometer. Activity is expressed as moles per minute per $\mathrm{ml}$ of mycelial extract, using the molar absorbance coefficient of $10500 \mathrm{M}^{-1} \mathrm{~cm}^{-1}$ (Beynon \& Bond 1994). All subsequent experiments were done at the optimum $\mathrm{pH}$. Chemicals used in assays were Analar grade or equivalent.

\section{pH ranges}

The effect of $\mathrm{pH}$ on activity was determined using mycelial extract over a $\mathrm{pH}$ range initially from 2.5 to 12 with each of four substrates at $0.15 \mathrm{~mm}$. Buffers, at $100 \mathrm{~mm}$, were: sodium phosphate/citric acid, $\mathrm{pH}$ values $2.5-5.5$; sodium phosphate/ phosphoric acid, $\mathrm{pH}$ values $5.5-8.0$; Tris $/ \mathrm{HCl}$, $\mathrm{pH}$ values 7.5 and 8.5 ; glycine $/ \mathrm{HCl}, \mathrm{pH}$ values from $8.5-10.5$ and sodium carbonate $/ \mathrm{NaOH}, \mathrm{pH}$ values from 9.5-11.5. Stock substrate solution $(50 \mu \mathrm{l})$ was mixed with $900 \mu \mathrm{l}$ buffer, followed by $50 \mu \mathrm{l}$ of mycelial extract, and the enzyme activity was measured at $35^{\circ}$ immediately after mixing. In some experiments $100 \mu \mathrm{l}$ of extract was used in the assays, and the buffer volume was adjusted accordingly. Any cuvettes giving nonlinear rates were discarded. All the $\mathrm{pH} /$ activity curves were carried out at least twice, using separate extracts. The curves shown in Fig. 1 are representative of the curves confirmed by replicate experiments. All subsequent experiments, below, were performed at the optimum $\mathrm{pH}$ for the enzyme activities, i.e. the buffer for assays of Arg-pNA hydrolysis and Leu-pNA hydrolysis was $100 \mathrm{~mm}$ Glycine/ $\mathrm{HCl}, \mathrm{pH} 8.5$; for Suc-AlaAla-Pro-Phe-pNA hydrolysis, $100 \mathrm{~mm} \mathrm{Na}_{2} \mathrm{HPO}_{4} /$ phosphoric acid or $100 \mathrm{~mm}$ MES, pH 6.5; and for Bz-Phe-Val-Arg-pNA hydrolysis, $100 \mathrm{~mm} \mathrm{Na} \mathrm{PO}_{4} /$ citric acid pH 2.5.

\section{Inhibitor sensitivities}

Stock inhibitor solution (10 or $20 \mu \mathrm{l}$ ), diluted to give the appropriate concentration (see Table 2), was mixed with $900 \mu$ l of $100 \mathrm{~mm}$ buffer. The buffer and $\mathrm{pH}$ were chosen for optimum activity with the substrate. Mycelial extract $(50 \mu \mathrm{l})$ was added, and then buffer, to give a total volume of $1 \mathrm{ml}$. Except where otherwise stated, inhibition was assayed immediately after adding the extract. When the inhibitor stock solution was in a solvent, the activity was compared to an assay containing the solvent at the same concentration.

\section{Requirement for divalent cations}

Mycelium from three pooled mycelial mats grown in $250 \mathrm{ml}$ flasks was extracted in approximately $5 \mathrm{ml} 0.1 \mathrm{M}$ MES (2-[N- 


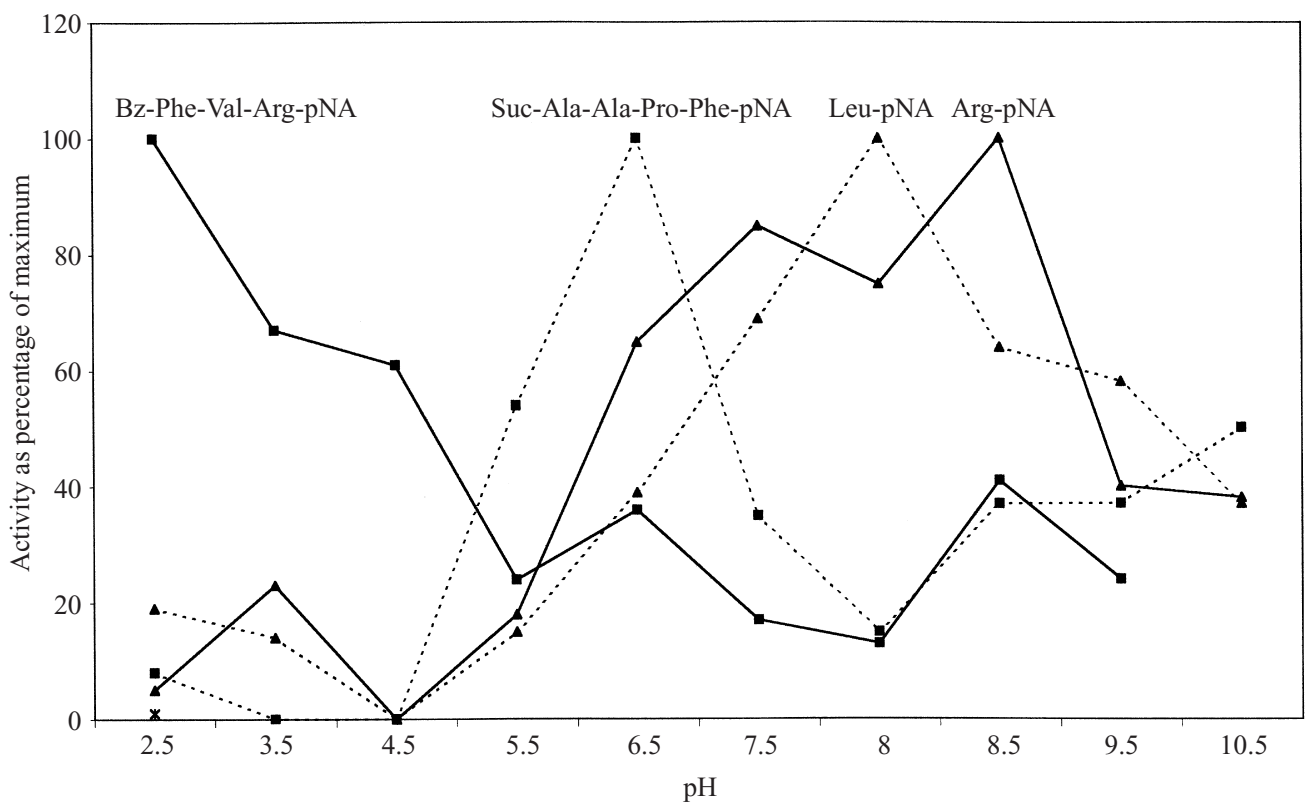

Fig. 1. Effect of $\mathrm{pH}$ on proteinase and peptidase activities. Symbols: Arg-pNA solid triangles, solid line; Bz-Phe-Val-Arg-pNA solid squares, solid line; Leu-pNA solid triangles, dotted line; Suc-Ala-Ala-Pro-Phe-pNA solid squares, dotted line. Activity is expressed as a percentage of maximal activity. Maximal activities in nmoles $\min ^{-1} \mathrm{ml}$ extract ${ }^{-1}$ for each substrate were: Arg-pNA, 4.0; Bz-PheVal-Arg-pNA, 8.3; Leu-pNA, 5.9 and Suc-Ala-Ala-Pro-Phe-pNA, 5.2. Each experiment was carried out at least twice, and the curves shown are representative of the results obtained in every experiment. The buffers used were as described under Methods. At the $\mathrm{pH}$ values where two buffer ranges overlapped, at $\mathrm{pH} 5.5,7.5$ and 8.5, the point given is the average of the two values obtained.

morpholino]ethanesulphonic acid) buffer at pH 6.5. MES was preferred to the sodium phosphate buffer used in the other extractions, to avoid precipitation of metal phosphates. Mycelial extract was dialysed twice for $12 \mathrm{~h}$ at $0^{\circ}$, each time in $2000 \mathrm{ml}$ of $100 \mathrm{~mm}$ Tris/ $\mathrm{HCl}$ buffer, $\mathrm{pH} \mathrm{7.5,} \mathrm{containing}$ $200 \mu \mathrm{M}$ EDTA. The activity of the dialysed extract against four substrates was measured before and after dialysis. The assays of dialysed extract were then repeated with the addition of a solution of each of seven divalent metal chlorides. For each assay $5 \mu \mathrm{l}$ of a $100 \mathrm{~mm}$ metal chloride stock solution was added to $1 \mathrm{ml}$ of the dialysed extract, thereby making a concentration of $500 \mu \mathrm{M}$ added metal in the extract. Then $100 \mu$ lof the mixed extract and metal chloride was used in the assay, with the dilution of the extract adjusted to maintain a total volume of $1 \mathrm{ml}$.

The manganese concentration dependence of activity against Arg-pNA was investigated by adding 5, 10, 50, 100 and $200 \mu \mathrm{l}$ of $100 \mathrm{~mm}$ manganese chloride to the assay, adjusting the dilution of the extract to maintain the volume of the assay mixture at $1 \mathrm{ml}$. Concentrations of manganese in these assays were thus $0.5,1.0,5.0,10$ and $20 \mathrm{~mm}$.

\section{Isoelectric focusing}

Isoelectric focusing was performed in a Rotofor cell (BioRad). Pooled mycelium from 16 mycelial mats each grown on $50 \mathrm{ml}$ peptone medium in a $250 \mathrm{ml}$ flask for $5 \mathrm{wk}$, was homogenised in ice-cold sodium phosphate buffer ( $\mathrm{pH}$ 6.5). The extract was dialysed overnight against $2000 \mathrm{ml}$ of $100 \mathrm{~mm}$ Tris/ $\mathrm{HCl}$, $\mathrm{pH} 7.5$, at $0^{\circ}$. The $53 \mathrm{ml}$ of extract obtained was mixed with $2 \mathrm{ml}$ ampholyte, $\mathrm{pH}$ range 3-10 (BioRad). The extract- ampholyte mixture was transferred to the pre-cooled Rotofor column $\left(5^{\circ}\right)$ immediately after mixing. Power was then applied and maintained at $12 \mathrm{~W}$ until $1 \mathrm{~h}$ after a plateau value of voltage indicated that the $\mathrm{pH}$ gradient had stabilised. Twenty samples were then collected by bleeding the column through manifold needles into ice-cold sample tubes, and their $\mathrm{pH}$ values immediately measured with a microprobe to record the $\mathrm{pH}$ gradient. Activities in the samples were assayed with four substrates. The activity of the extract against Arg-pNA was measured both before and after dialysis, and before and after mixing with ampholyte, to check that activity was still present after these procedures.

\section{RESULTS}

\section{pH sensitivities of activities}

The activities against substrates of differing composition, and their $\mathrm{pH}$ optima, inhibitor sensitivities and $\mathrm{pI}$ values, indicated a number of distinct proteinase activities present in the mycelial extract. Peptidase and proteinase substrates hydrolysed were Arg-pNA, Leu-pNA, Bz-Phe-Val-Arg-pNA, BzTyr-pNA， Suc-Ala-Ala-Pro-Leu-pNA， Suc-Ala-Ala-Pro-PhepNA, and Suc-Ala-Ala-Val-Ala-pNA. Other substrates which were not hydrolysed were Glu-pNA, Ac-Ala-pNA, Ac-LeupNA, Bz-Arg-pNA, Suc-Ala-Ala-Val--pNA and Suc-Phe-pNA. Substrates blocked at the amino end by either a succinyl ('Suc') or benzoyl ('Bz') group, if hydrolysed indicate the activity of an endopeptidase or proteinase capable of breaking bonds in the middle of polypeptide chain (Beynon \& Bond 1994). Four of the activities found were further characterised 
Table 1. Percentage inhibition of enzyme activities of mycelial extract against five synthetic protease substrates. Molarities and concentrations are those in the assay mixture.

\begin{tabular}{lllllll}
\hline & $\begin{array}{l}\text { Conc. } \\
\text { in assay }\end{array}$ & $\begin{array}{l}\text { Leu- } \\
\text { pNA }\end{array}$ & $\begin{array}{l}\text { Arg- } \\
\text { pNA }\end{array}$ & $\begin{array}{l}\text { Suc-(Ala) })_{2} \\
\text { Pro-Phe-pNA }\end{array}$ & $\begin{array}{l}\text { Bz-Phe-Val- } \\
\text { Arg-pNA }\end{array}$ & $\begin{array}{l}\text { Suc-(Ala) }{ }_{2} \text {-Pro- } \\
\text { Leu-pNA }\end{array}$ \\
\hline Inhibitor & & & & & & \\
PMSF & $1 \mathrm{mM}$ & - & - & 41 & - & - \\
EDTA & $1 \mathrm{mM}$ & 50 & - & - & - & - \\
1,10-phenanthroline & $1 \mathrm{mM}$ & 55 & - & - & - & 70 \\
E64 & $100 \mathrm{~mm}$ & 70 & - & - & - & nd \\
amino-benzamidine & $1 \mathrm{mM}$ & - & ${ }^{*} 24$ & - & \\
\hline
\end{tabular}

* Inhibition of activity against Arg-pNA by aminobenzamidine was obtained only after 20 min pre-incubation of inhibitor with mycelial extract before adding substrate. No inhibition was obtained with pepstatin, iodoacetate, iodoacetamide, TLCK, TPCK, soybean trypsin inhibitor, lima bean trypsin inhibitor or trypsin/chymotrypsin inhibitor.

Table 2. (a) The effect of removal of metal ions by double dialysis against $200 \mu \mathrm{M}$ EDTA followed by readdition of various divalent metal cations (to $500 \mu \mathrm{M})$. (b) Concentration/reactivation curve for $\mathrm{Mn}^{++}$mediated reactivation of activity against Arg- $p \mathrm{NA}^{\text {. Activities are in nmoles min }}{ }^{-1} \mathrm{ml}$ extract ${ }^{-1}$ in both (a) and (b).

(a)

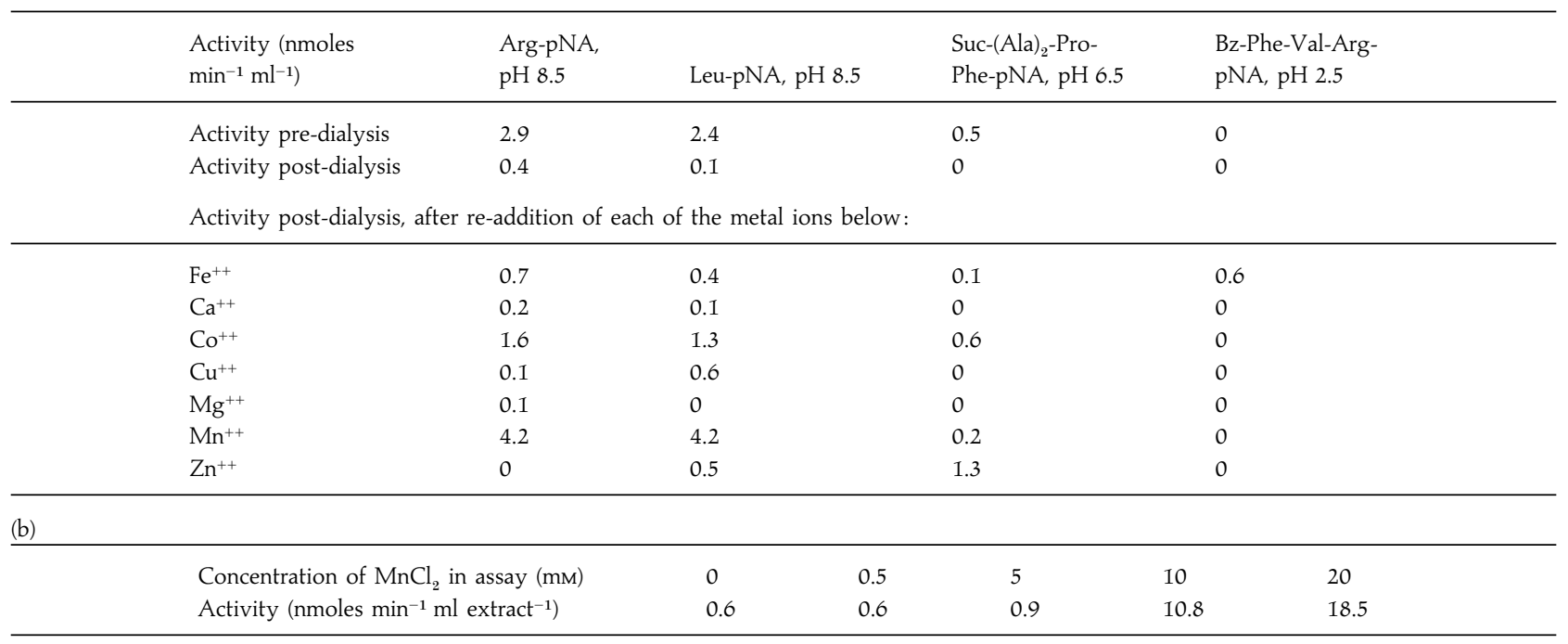

by $\mathrm{pH}$ /activity curves (Fig. 1). Activity against the peptidase substrate Arg-pNA was optimal at around $\mathrm{pH} 8.5$, and against Leu-pNA at pH 8.0. The proteinase activities differed greatly in $\mathrm{pH}$ optima. Suc-Ala-Ala-Pro-Phe-pNA was hydrolysed fastest at $\mathrm{pH} 6.5$, but the highest rate of activity against BzPhe-Val-Arg-pNA was at $\mathrm{pH} 2.5$, the lowest $\mathrm{pH}$ achievable in the assays, with a shoulder between $\mathrm{pH} 3.5$ and 4.5 indicating a second activity peak. No hydrolysis of this substrate was found at $\mathrm{pH} 2.5$ in the absence of added mycelial extract.

\section{Inhibitor sensitivity of activities}

The different inhibitor sensitivities of activities against five substrates (Table 1) confirmed their distinct characteristics. Activity with both Suc-Ala-Ala-Pro-Phe-pNA and Suc-AlaAla-Pro-Leu-pNA was inhibited by the serine proteinase inhibitor PMSF (phenylmethanesulphonyl fluoride), although only the activity against Suc-Ala-Ala-Pro-Leu-pNA was sensitive to the cysteine proteinase inhibitor E64 (L-transepoxysuccinyl-leucylamide-(4-guanidino)-butane), which also inhibited activity against Leu-pNA. Activity with Leu-pNA had metallopeptidase characteristics, being inhibited by the chelators EDTA and 1,10-phenanthroline, and also by E 64 .
Activity with Arg-pNA was not affected by any inhibitors apart from aminobenzamidine, a reversible inhibitor of trypsinlike enzymes, that developed only after incubating the extract with the inhibitor for 20 min before adding the substrate and buffer to the assay (Table 1). Activity against Bz-Phe-Val-ArgpNA could not be inhibited with any of the 13 inhibitors tried.

\section{The effects of divalent metal ions}

Dialysis to remove metal ions (Table 2) greatly decreased the activity of mycelial extract with both Arg-pNA and Leu-pNA. There was also a decrease with Suc-Ala-Ala-Pro-Phe-pNA, although the initial activity was too low for this effect to be unequivocal. Readdition of manganese, and to a lesser extent cobalt, resulted in an increase to higher than pre-dialysis levels of activity against both Arg-pNA and Leu-pNA. Neither activity was restored significantly by the readdition of zinc. Activity against Suc-Ala-Ala-Pro-Phe-pNA, a serine protease in terms of inhibitor sensitivity, was restored to higher than pre-dialysis levels by zinc, but not manganese. Activity on Arg-pNA measured in relation to manganese concentration (Table 2b) showed a sharp increase between 5 and $10 \mathrm{~mm}$, and was still increasing at $20 \mathrm{~mm}$. 


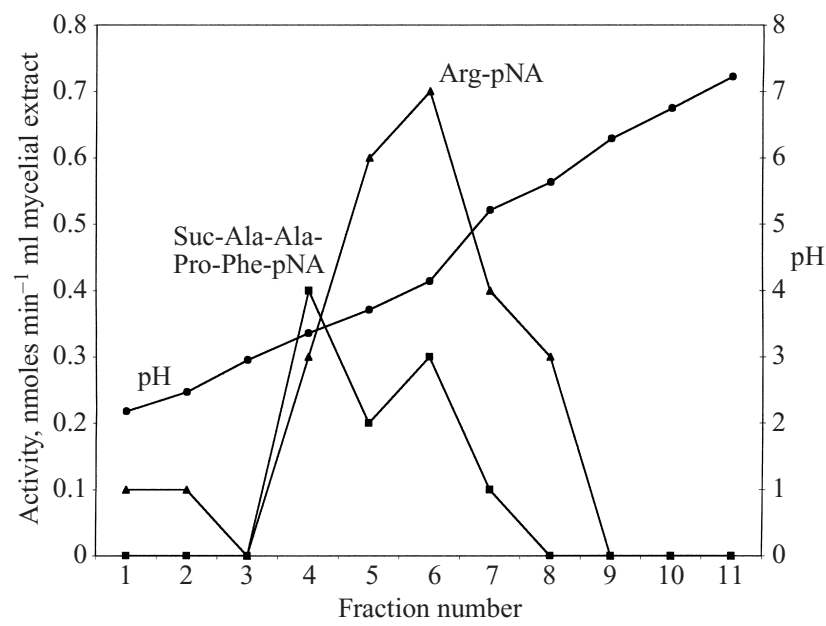

Fig. 2. Isoelectric focusing using a Rotofor cell. Substrates: Arg-pNA activity; $\mathbf{\square}$, Suc-(Ala) ${ }_{2}$-Pro-Phe-pNA; O, pH gradient. Activities are given in nmoles $\mathrm{min}^{-1} \mathrm{ml}$ extract ${ }^{-1}$. Two replicate runs were carried out for each substrate (one representative run for each shown here). No significant activity against any other of the substrates in Fig. 1 was recovered from the column.

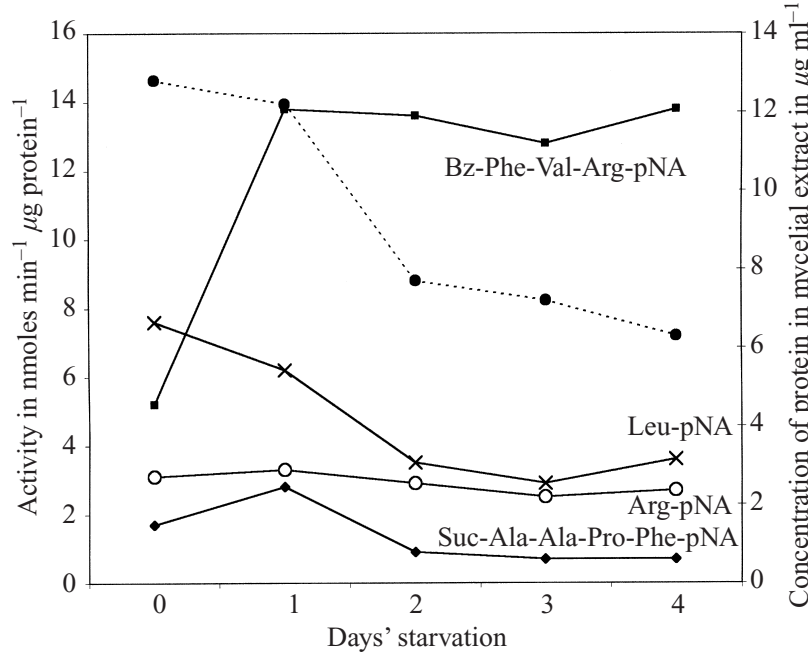

Fig. 3. Activity against four substrates in extracts of mycelium that had been starved for $0,1,2,3$ and 4 days, and total protein as $\mu \mathrm{g} / \mathrm{ml}$ of mycelial extract. Results are means from duplicate extracts, each assayed in triplicate. Activities are given in nmoles $\mathrm{min}^{-1} \mu \mathrm{g}$ of protein $^{-1}$. Substrates: $\mathbf{D}$, Bz-Phe-Val-Arg-pNA; X, Leu-pNA; O, Arg-pNA; $\bullet$, Suc-Ala-Ala-Pro-Phe-pNA. Dotted line indicates total protein.

\section{Isoelectric points}

Isoelectric focusing (Fig. 2) revealed that activity against ArgpNA has pI 3.4, and activity against Suc-Ala-Ala-Pro-PhepNA has pI 4.3. Activity against Bz-Phe-Val-Arg-pNA and Leu-pNA was not recovered from this procedure.

\section{Differential effects of starvation on activities}

Two of the enzyme activities increased as a result of starving the mycelium prior to assay (Fig. 3). Activity against Bz-Phe-
Val-Arg-pNA was more than doubled in mycelium that had been starved for 1, 2, 3 or $4 \mathrm{~d}$. Activity against Suc-Ala-AlaPro-Phe-pNA was nearly doubled in mycelium starved for one day, but decreased again after 2, 3 or $4 \mathrm{~d}$ starvation. Starvation halved activity against Leu-pNA after $2 \mathrm{~d}$, and it was also low at 3 and $4 \mathrm{~d}$ starved cultures. The activity against Arg-pNA was relatively unaffected by starvation, remaining steady in all treatments.

\section{DISCUSSION}

Two of the enzyme activities characterised showed the type of regulation that we sought, increasing on starvation - the activities against Suc-Ala-Ala-Pro-Phe-pNA and Bz-Phe-ValArg-pNA. They would therefore both appear to be candidates for a role in the breakdown of intracellular protein. However, the very low $\mathrm{pH}$ optimum of Benz-Phe-Val-Arg-pNA activity suggests a vacuolar location and a lysosomal role in dead or dying cells, or in extracellular proteolysis, rather than in regulating the cellular processes of growing, healthy mycelium. In its inhibitor insensitivity it shows the robustness characteristic of extracellular enzymes. Serpula lacrymans, unlike other wood decaying basidiomycetes, exudes a widelydiffusing and potent proteinase (Venables \& Watkinson 1989b). Its mycelium also autolyses very readily under nitrogen starvation on carbon-rich media, with accompanying acidification of the culture medium to $\mathrm{pH} 2.8$. This destructive proteolysis might be the role of the highly active acid endoprotease identified by its hydrolysis of the substrate BzPhe-Val-Arg-pNA. The serine protease detected with SucAla-Ala-Pro-Phe-pNA seems the more likely candidate for an enzyme with the function of releasing amino acid in a controlled manner from stored protein without cell damage. Starvation induced a transient activation of this enzyme, in keeping with a physiological role in healthy mycelium which has an average $\mathrm{pH}$ in S. lacrymans of 6.5. Its activity was highest in mycelium starved for only one day, and after longer periods of starvation activity was much lower. Inhibition by PMSF tends to characterise this activity as a serine protease, a type known from many fungi (North 1982), and known to play many physiological roles, for example in attack on insects by entomopathogenic fungi. The results suggest a role for metals in activation of the serine protease-type activity found in S. lacrymans. Dialysis for $12 \mathrm{~h}$ reduced activity, and readdition of zinc restored it. Serine proteinases typically have a stabilising metal and it is possible that zinc plays this role. Addition of chelators did not inhibit activity, which could be interpreted to mean that the metal has a stabilising rather than a catalytic role. Investigation of $S$. lacrymans intracellular proteases by SDS-PAGE and azocaseinase assay showed relatively low serine protease activity, although a serine protease sensitive to PMSF was found in the wood decay fungus Coriolus versicolor (Wadekar, North \& Watkinson 1995). A serine proteinase characterised from Agaricus bisporus fruiting bodies (Burton et al. 1993) was implicated in protein hydrolysis for mobilisation of amino acids from stipe to cap during maturation of harvested sporophores (Burton et al. 1997), a similar function to that postulated for the S. lacrymans serine proteinase described here. Other serine proteinases are 
involved in attack on the insect host by entomopathogenic fungi (Khatchatourians 1996). It appears that serine proteinases are widespread in fungi, and play a variety of physiological roles.

The two peptidase activities stimulated by readdition of cobalt and manganese after dialysis, and active against LeupNA and Arg-pNA, had similar, slightly alkaline pH optima, and neither was activated by starving the mycelium. Inhibition by the chelators EDTA and 1,10-phenanthroline confirmed the metalloproteinase character of the activity against LeupNA. All three effective inhibitors of this enzyme were optimally effective at $\mathrm{pH} 4.5$ (data not shown). Leu-pNA activity was greatly reduced by starvation, and the fact that it decreases when growth stops, but is high in well-nourished mycelium, suggests a role for this enzyme in active mycelial growth. An example of a proteases playing a part in active growth are those known to be required for chitin synthetase activation for wall growth in Mucor rouxii and Candida albicans (North 1982, Gooday 1995).

The other peptidase activity, against Arg-pNA, although similar to that against Leu-pNA in being activated by readdition of manganese and cobalt after double dialysis, was distinguished from it in being unaffected by the chelators EDTA or 1,10-phenanthroline. Moreover, it was inhibited only by aminobenzamidine, which did not inhibit activity on Leu-pNA. Its activity was unaffected by the nutritional state of the mycelium.

The large effect of readdition of manganese on Leu-pNA and Arg-pNA hydrolysing activity after dialysis is noteworthy. It may not however be representative of physiological activation of the enzymes. Manganese dependent proteases are rare (Frausto da Silva \& Williams 1991), with only cytosolic proline aminopeptidase and proline dipeptidase reported (Auld 1995). It is therefore most likely the activation of these enzymes by manganese and cobalt seen in our experiments was an artefact, and that zinc is the metal bound under physiological conditions. Some Zn metalloproteinases with two zinc atoms can be reconstituted with one manganese and one zinc atom to give far higher activity, as was shown by Carpenter \& Vahl (1973) with a bovine leucine aminopeptidase. Our reactivation curve, where activity against ArgpNA continued to increase as manganese was raised up to the high level of $20 \mathrm{~mm}$, indicates a relatively weak binding of manganese atoms. Zinc is bound 35 times more strongly than manganese by zinc metalloproteases (Carpenter \& Vahl 1973), and cytosolic zinc concentration is typically twenty times that of manganese (Auld 1995). Therefore, we consider that manganese binding may not significantly affect activity in vivo, even if it gives an enzyme with above-normal activity in assays.

We conclude that there is evidence for two intracellular proteinase activities implicated in mycelial development in Serpula lacrymans, one active under acid and the other under neutral conditions, which can be assayed with the substrates Bz-Phe-Val-Arg-pNA and Suc-Ala-Ala-Pro-Phe-pNA respectively. We speculate that the role of the acid proteinase is lysosomal, in proteolysis during hyphal death, and may play a part in creating the empty, aseptate 'vessel' hyphae of mycelial cords. It may also be responsible for the unusually active extracellular proteolysis which is characteristic of $S$. lacrymans compared with other wood decay fungi (Venables \& Watkinson 1989b). S. lacrymans acidifies Czapek-Dox medium to $\mathrm{pH}$ as low as 2.5 , the optimum $\mathrm{pH}$ for this enzyme. The neutral proteinase appears to have the characteristics expected in an intracellular proteinase concerned with the mobilisation of protein stores within a living mycelial system. Its $\mathrm{pH}$ optimum is the same as the $\mathrm{pH}$ of fungal cytoplasm, and it is only transiently activated in response to starvation, rather than remaining high during starvation-induced autolysis. This enzyme is therefore the most appropriate for further investigation of the activation pathway of nitrogen reallocation during mycelial foraging in this fungus.

\section{ACKNOWLEDGEMENTS}

S.C.W. is very grateful for the opportunity to work and learn under the direction of the late David Wood at Horticulture Research International during study leave. The authors would also like to acknowledge helpfu discussion of the results with Paul Wood (University of Bristol). The work was funded by grants to K.S.B. from the Biotechnology and Biological Sciences Research Council and the Ministry of Agriculture, Fisheries and Food.

We dedicate this publication to the memory of David Wood.

\section{REFERENCES}

Auld, D. S. (1995) Removal and replacement of metal ion in metallopeptidases. In Methods in Enzymology (A. J. Barrett, ed.) 248: 228-242.

Beynon, R. J. \& Bond, J. S. (1994) Proteolytic Enzymes: a practical approach. IRL Press, Oxford.

Boddy, L. (1993) Saprotrophic cord-forming fungi: warfare strategies and other ecological aspects. Mycological Research 97: 641-655.

Boddy, L. \& Watkinson, S. C. (1995) Wood decomposition, higher fungi, and their role in nutrient redistribution. Canadian Journal of Botany 73 (Suppl.): S1377-S1383.

Bradford, M. M. (1976) A rapid and sensitive method for the quantitation of microgramme quantities of protein using the principle of protein-dye binding. Analytical Biochemistry 72 : 248-254.

Burton, K. S., Partis, M. D., Wood, D. A. \& Thurston, C. F. (1997) Accumulation of serine proteinase in senescent sporophores of the cultivated mushroom, Agaricus bisporus. Mycological Research 101 : 146-152.

Burton, K. S., Wood, D. A., Thurston, C. F. \& Barker, P. J. (1993) Purification and characterization of a serine proteinase from senescent sporophores of the commercial mushroom Agaricus bisporus. Journal of General Microbiology 139: 1379-1386.

Carpenter, F. H. \& Vahl, J. M. (1973) Leucine aminopeptidase (bovine lens). Journal of Biological Chemistry 248: 294-304.

Dighton, J. (1997) Nutrient cycling by saprotrophic fungi in terrestrial habitats. In The Mycota. Vol. IV. Environmental and Microbial Relationships (D. T. Wicklow \& Soderstrom, B., eds): 271-279. Springer Verlag, Berlin. Gooday, G. W. (1995) Cell walls. In The Growing Fungus (N. A. R. Gow \& G. M. Gadd, eds) : 43-62. Chapman \& Hall, London.

Khatchatourians, G. G. (1996) Biochemistry and molecular biology of entomopathogenic fungi. In The Mycota. Vol. VI. Human and Animal Relationships (D. H. Howard \& J. D. Miller, eds): 331-363. Springer Verlag, Berlin.

Leake, J. R. \& Read, D. J. (1997) Mycorrhizal fungi in terrestrial habitats. In The Mycota. Vol. IV. Environmental and Microbial Relationships (D. T. Wicklow \& B. Soderstrom, eds): 281-301. Springer Verlag, Berlin.

North, M. J. (1982) Comparative biochemistry of proteinases of eukaryotic organisms. Microbiological Reviews 46: 308-340.

Frausto da Silva, J. J. R. \& Williams, R. J. P. (1991) The Biological Chemistry of the Elements: the inorganic chemistry of life. Clarendon Press, Oxford.

Venables, C. E. \& Watkinson, S. C. (1989a) Medium-induced changes in patterns of free and combined amino acids in mycelium of Serpula lacrymans. Mycological Research 92 : 273-277. 
Venables, C. E. \& Watkinson, S. C. (1989b) Production and localisation of proteinases in colonies of timber decaying basidiomycete fungi. Journal of General Microbiology 135: 1369-1374.

Wadekar, R. V., North, M. J. \& Watkinson, S. C. (1995) Proteolytic activities in two wood-decaying basidiomycete fungi, Serpula lacrymans and Coriolus versicolor. Microbiology 141: 1575-1583.

Watkinson, S. C. (1984) Inhibition of growth and development of Serpula lacrymans by the non-metabolised amino acid analogue 2-aminoisobutyric acid. FEMS Microbiology Letters 24: 247-250.
Watkinson, S. C. (1999) Metabolism and differentiation in basidiomycete mycelium. In The Fungal Colony (N. A. R. Gow, ed.): 126-156 Cambridge University Press, Cambridge.

Watkinson, S. C., Davison, E. M. \& Bramah, J. (1981) The effect of nitrogen availability on growth and celluloysis by Serpula lacrymans. New Phytologist 89: $295-305$

Corresponding Editor: H.-P. Molitoris 